\title{
新しい舶用衛星追尾アンテナの開発に関する研究
}

\section{Development of New Satellite Tracking Antenna For Maritime Broad Band Network System}

鈴木 雅人 $*$ 大津 皓平 ${ }^{* *} \cdot$ 浦 康彦***

\author{
Masato SUZUKI, Kohei OHTSU and Yasuhiko URA
}

\begin{abstract}
Authors designed and developed a new-type of satellite tracking antenna for Maritime Broad Band Communication and a Luneburg Lens Antenna applied in this study because this lens antenna has distinctive functions to communicate with multiple satellites simultaneously. For the sake of tracking a target satellite accurately on board, authors used a gimbals-type of stable platform on which a Luneburg Lens Antenna was installed. Stochastic autoregressive models supported to predict ship's rolling, pitching and yawing behaviors in the stabilizing mechanism. In this paper, the authors describe the principle of this new type of ship's antenna system and evaluate the results of the actual experiments on board.
\end{abstract}

Keywords : Holizontal Stabilizing Platform,Luneburg Lens Antenna, AR-model, Satellite Tracking Antenna キーワード: 水平安定台、ルネベルグレンズアンテナ、AR モデル。舶用衛星追尾アンテナ

\section{1. はじめに}

今日海上と陸上を結ぶ通信基盤として、衛星を用 いた船陸間通信は必要不可久となっている。しかし ながら、海上通信と陸上通信を比較するとその通信 容量·速度などの格差は比較にならないほど大きい。 その理由はニーズの薄い割にサービスエリアが大き いことによるが、他の原因として衛星との送受信を 行うアンテナが動摇する船上に置かれていることか ら船上のアンテナが何らかの衛星追尾機能をもつ必 要があり、しかもその要求性能は $\mathrm{Ku}$ バンドなどい わゆるブロードバンド帯域になるほど高い精度が求 められ、結果として高価になることも考えられる。 しかしながら、近年の船員の少人数化、多国籍化等 を考えると船舶の運航管理などにリアルタイムでの 画像、音声通信を使って陸上から支援を受ける形で の新たな船陸間協調運航形態への移行が避けて通れ なくなってきている。著者等が始めた海洋ブロード
バンドプロジェクト研究はこのような背景により始 めたものである。

ところで、このような通信基盤整備に核となる技 術には、移動体でのアンテナ送受信技術がある。そ の現状を見ると、今日船舶用衛星通信に用いられる アンテナはパラボラアンテナである。パラボラアン テナはその原理上単一の衛星との交信に用いられる ので船上で複数の衛星の情報が欲しい時、別々に高 価なアンテナを用意するか、目標衛星に追尾させる ためアンテナ方向を移動させねばならない。

このよう状況を改善するため著者等は、複数衛星 との同時交信が可能なアンテナとして、アンテナ部 に最近開発されたルネベルグアンテナ(Luneburg Antenna)と呼ばれるレンズ状アンテナを使ったシス テムの実用化を目指している(1)。

ここでは、このルネベルグレンズアンテナを使っ
* 正会員 東京海洋大学大学院

** 名誉会員 東京海洋大学海洋工学部

( $\mathbf{T} 135-8533$

( $\bar{T} 135 \cdot 8533$
東京都江東区越中島 2-1-6)

masuzuki@e.kaiyodai.ac.jp

***非会員 SEI ハイブリッド株式会社 
た複数衛星同時交信可能なアンテナシステムの原理 と開発されたシステムおよびこのアンテナが安定し て衛星を追尾できるために必要な水平安定台の性能 について実証的に示すことを目的とする。

\section{2. 街量追层システムの模成}

\section{1 ルネベルグレンズアンテナ}

本研究のアンテナには、住友電気工業社製のルネ ベルグレンズアンテナを使用した。このレンズアン テナの形状は Fig.1 に示すように球状が最も良い(1)。 そしてこの球状アンテナは図の球の半径中心に向か って誘電率 $\mathrm{n}$ が半径中心方向に

$$
n=\sqrt{2-\left(\frac{r}{R}\right)^{2}}
$$

に従って変化する。ここで $\mathrm{R}$ は球の半径で $\mathrm{r}$ は半径 方向の長さである。このような誘電率の連続的変化 によって、衛星からの電波は任意の一点で焦点に絞 られる。以前はこの誘電率の連続的変化が工作上困 難であったが、最近、住友電気工業によって量産が 可能となった。

いま、ある衛星から来る電波がこの球面に到達し 内部に入射する場合、Fig.1 に示すように電波は式(1) に従って曲がり、最終的に球面の 1 点で焦点を結ぶ ことになる。この焦点にピックアップを移動してや れば受信が可能となる。他の衛星の場合は、焦点は 別の位置に結ぶので別のピックアップをその点に移 動してやれば良い。かくしてピックアップの数だけ 衛星との交信が可能となる。ところで地上の固定局 通信のようにアンテナが固定されている場合はピッ クアップの移動は簡単である。しかしながら、移動 通信のように固定されていない場合、ピックアップ 部はなんらかの追尾機能が必要となる。それでも衛 星からの電波の受信の場合は比較的簡単であるが、 衛星に向けて送信する場合、他の衛星へ送信電波が 到達しないように厳しい基準が設けられている(電 波法施行規則第 30 条八の 2 )。

その基準によると、 $\mathrm{Ku}$ バンド帯での交信を衛星と 行う場合、Fig.2 に示すように、移動体から衛星に向 けての送信精度が、

$$
\begin{aligned}
& \text { ローリング<0.2 度 } \\
& \text { ピッチング<0.2 度 } \\
& \text { ヨーイング<0.2 度 }
\end{aligned}
$$

という極めて高精度の追尾機能が必要である。

船体運動は 3 軸の並進運動と 3 軸の回転運動、あ わせて 6 軸の運動をしているが、衛星への距離が非

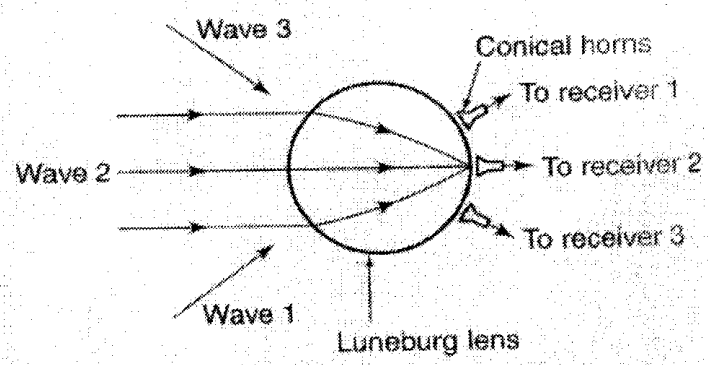

Fig.1 Luneburg Lens Antenna

常に遠距離のため、これらのうち並進運動に起因す る影響はほとんど無い。したがって回転運動のみを 追従させれば良い。

ところで、船舶の場合は他の移動体と異なり極め て大きな動摇が予想され、アンテナ上部のピックア ップのスキャンだけでは満足な追尾性能が得られな いことが予想される。

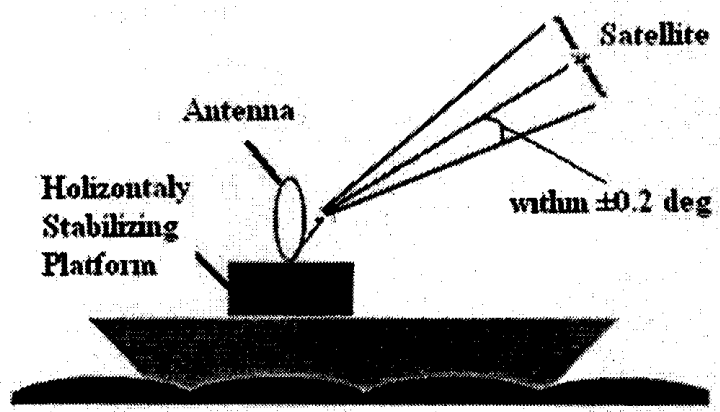

Fig.2 Necessary Accuracies for Satellite Communication

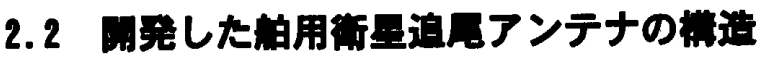

著者等はこの精度実現のために 2 段階の追尾方式 を採用した。すなわち、

（1）アンテナ基部に水平安定台 ${ }^{(2)(3)}$ を設け船体の大 角度の動摇を減摇させ、精度を各方向に対して 0.5 度以内とする。

（2）国際基準である 0.2 度以内への追い込みはピッ クアップの追従によって行う。この追従はステップ アレー方式の追従によって電気的に行う。

という方式である。

Fig.3 は全体の構造を示す。水平安定台はピッチン グ、ローリングをジンバル方式で回転させ、ヨーイ ング方向はターンテーブルで追従させる。

また上部はアンテナ部であるが、アンテナを球状に すると工作上困難であるので半球状とし、下部に円 形の鐸状の反射板（アルミ）を設け、この反射板に よって電波を反射させた後、半球内部に入射電波を 導く。 


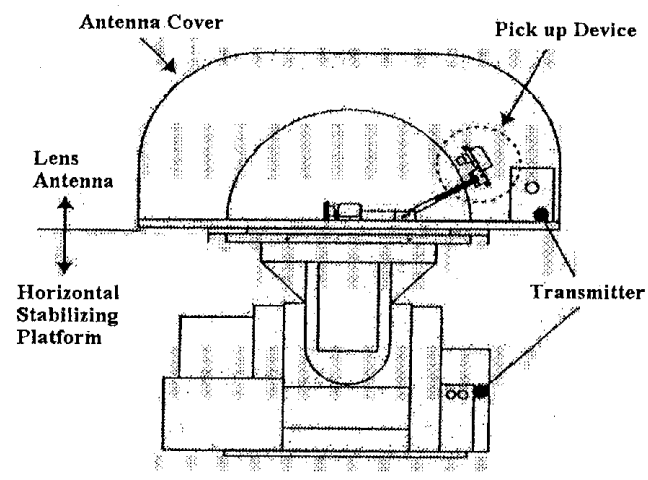

Fig.3 Architecture

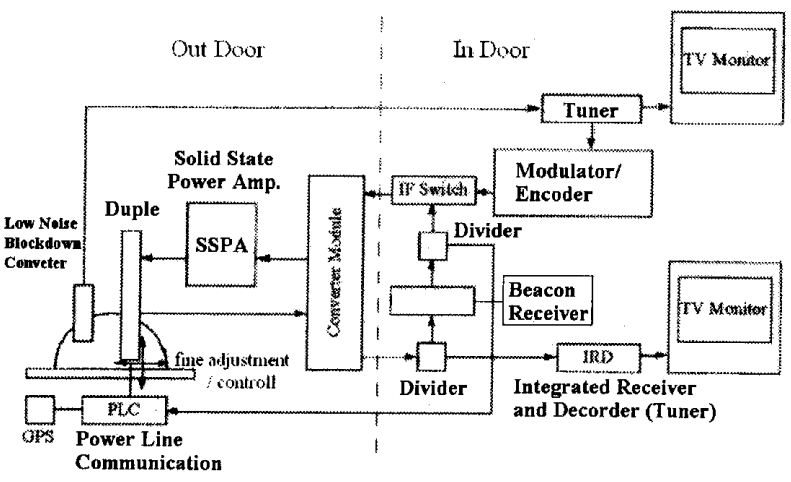

Fig.4 Satellite Communication System

Fig.4 は電気的なブロック図を示す。（2）の最終的 に衛星ビームを正確に追従するステップアレー方式 はよく知られていること(4) およびその精度の向上 が本論文の目的ではないことにより、以下の水平安 定台の水平安定方式について述べる(2)(3)。

\section{2 水平安定白}

ここで開発した安定台を Fig.5に示す。XYZ 軸の 各回転軸のうち船体上に置かれた光ファイバージ ヤイロによって測定される船体のローリング方向 とピッチング方向は、モータの回転によってジンバ ル方式でこれらの方向に対する角度補償を行う。ヨ 一イングは船のジャイロコンパスから船首方位を 受けてターンテーブルを回転することによって補 償を行う。

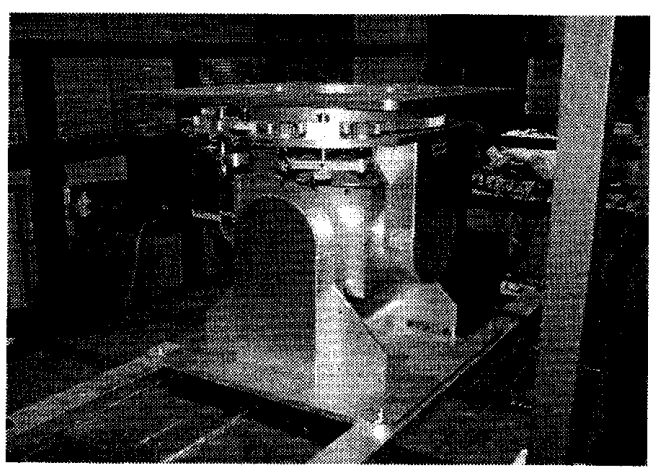

Fig.5 Horizontal Stabilizing Platform

\section{3. 制御アルゴリズム \\ 3.1 基本となる水平安定法}

船体上に水平な平面を構築するための基本となる 考え方は、船体の動摇に対し逆振幅・同位相で動摇 安定台のプラットホームを動作させることである。 すなわち、例えば Fig.6 に示すように船体が左に 10 度傾くとすると、動摇安定台のプラットホームは、 船体に対して-10 度傾くことで、プラットホームは 水平を保つことができる。

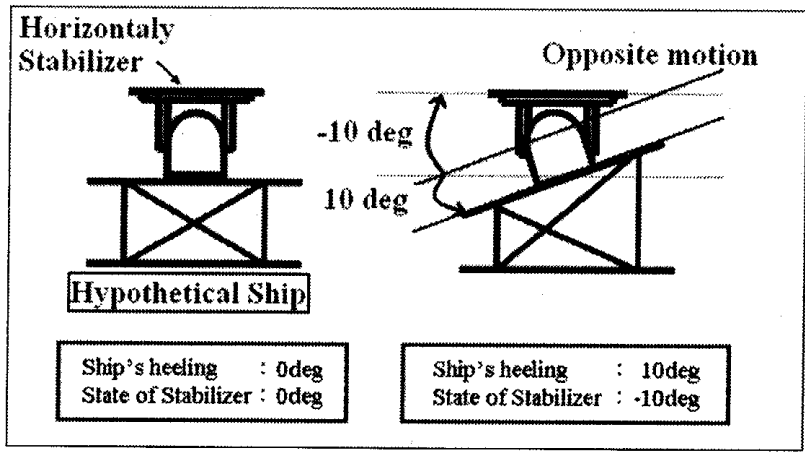

Fig.6 Ship Motion Reduction control

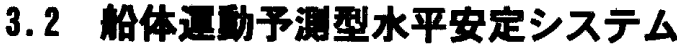

原理的には 3.1 で説明したことでこのシステムは 動くが、実際にはアクチュエータの追従遅れ等によ り偏差が生じるため、このまま単純な離散型 PID フ イードバックをこの基本となる水平安定システムに 適用すると、Fig.7 のように安定精度が悪い。この時、 サンプリングタイムは水平安定台の動きが離散制御 特有のステップ状にならないために約 $0.06 \mathrm{sec} と$ 設 定されている。そこで著者等は、船体運動を何らか の方法で予測し、その予測結果に追従するフィード フォワード制御機能を付加することにより、追従遅 れによる誤差を補償することを考えた ${ }^{(3)}$ 。そしてそ の予測モデルとして自己回帰モデル(Auto Regressive Model, AR model)による予測を用いてその船体の運 動を予測し、Fig.8に示すようにアクチュエータの追 従遅れの時間分を先行出力することで、より水平度 の維持精度を向上させることを試みた。

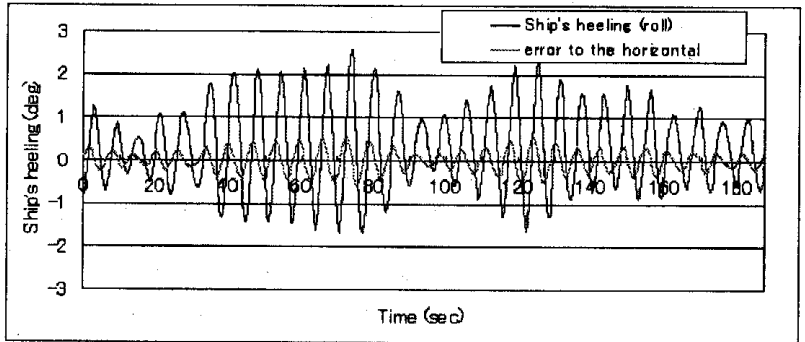

Fig.7 PID control without AR-model (rolling) 


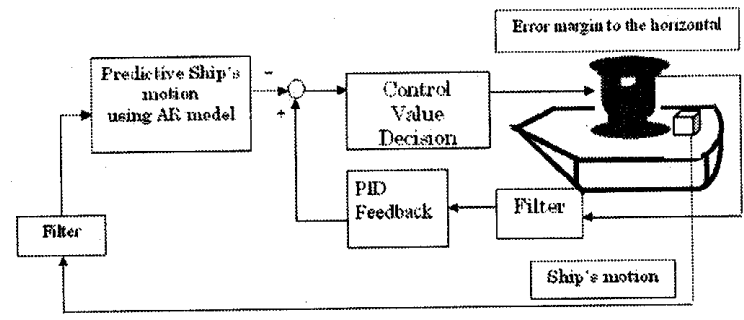

Fig.8 Ship Motion Cancel Control with AR model

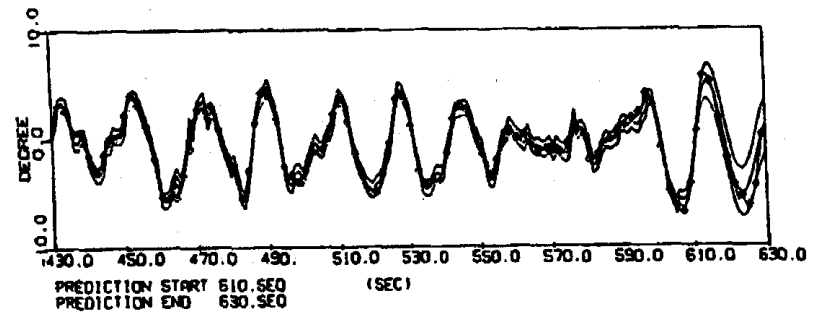

Fig.9 Long-term Prediction with AR Model in Rolling Motion

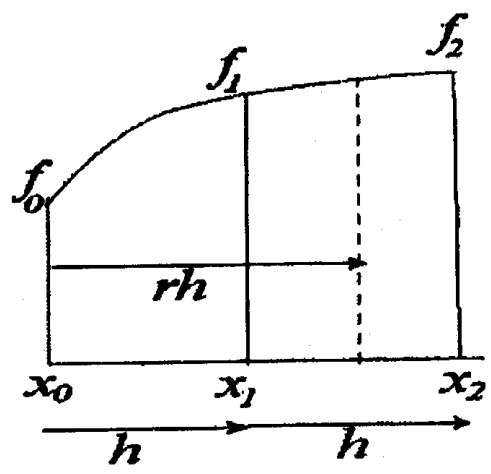

Fig.10 Interpolating of Predictive Value

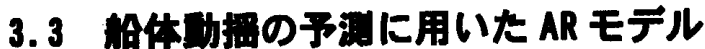

船体の動摇角度の予測に用いたモデルは

$x(n)=a(1) x(n-1)+a(2) x(n-2)+\cdots+a(M) x(n-M)+v(n)$

で表される統計モデルである。ここで $x(n)$ は時刻 $\mathrm{n}$ における船体の動摇、 $M$ は著者等が多用してきた 最小 AIC 法(5) (6)で求めた次数である。 $a(M)$ は自己 回帰倸数、 $v(n)$ は予測誤差である。Fig.9 はこの方 法によって求めたあるコンテナ船のローリングの予 測結果で、610秒近くまでのデータを用いて最小 AIC 法を適用して AR モデルを構成し、その先をカルマ ンフィルタを使い 20 秒間にわたって予測した結果 で、真ん中の線が予測値、点が実測値、両側の線が 標準偏差である。ここではローリングのみ描かれて いるがピッチングも同じように十分な予測精度で船 体運動を予測しており、本システムで利用するよう な高々 1 期先予測においても十分な予測精度を持つ と考えられる。
ただし、この船体運動を表す統計モデルは船体運 動の観測時間間隔としては 0.5 から 1 秒程度が最も 精度が良くかつ実用的である。しかるに追従遅れ補 償を行うための予測時間はより短くなることが予想 される。予備実験として実験室内でローリング、ピ ッチングに対する水平台の応答遅れを計測した所、 ほぼ 100msec の遅れを生じており、予測区間として は $100 \mathrm{msec}$ 程度が最適であることが分かった。(し かし、ヨーイングについてはターンテーブル装置が 無いため確認できなかった)。したがって船体運動の 予測周期を使って最適なより短い区間での予測が必 要となる。ここではその中間での予測值を得る方法 として、Figi.10に示すように 2 次補間公式

$$
\begin{aligned}
& f(x)=f_{0}+r \Delta f_{0}+\frac{r(r-1)}{2} \Delta^{2} f_{0}, \\
& r=\frac{x-x_{0}}{h}, 0 \leq r \leq 2, \\
& \Delta^{2} f_{0}=\Delta f_{1}-\Delta f_{0}=f_{2}-2 f_{0}+f_{1}, \Delta f_{0} \\
& =f_{1}-f_{0}, \Delta f_{1}=f_{2}-f_{1}
\end{aligned}
$$

を使って最適な予測時間における予測值を内挿法に よって求めることとした。

\section{4. 突船党要 \\ 4.1 设是境}

本研究では以上のような水平安定台付き衛星追尾 アンテナシステムを用いて、本大学所属の練習船汐 路丸において実験を行った。Fig.11 はその設置位置 を示すが、船体強度を考慮し中央デッキとした。そ のため一部の方位で構造物により電波が遮られアン テナ受信レベルが低下することとなった。統計モデ ル作成のためのデータが周期 $0.5 \mathrm{sec}$ で前もって採ら れた約 1000 点の観測データに最小 AIC 法によるあ てはめを行って求めたモデルを使った。その時の次 数は 7 である。

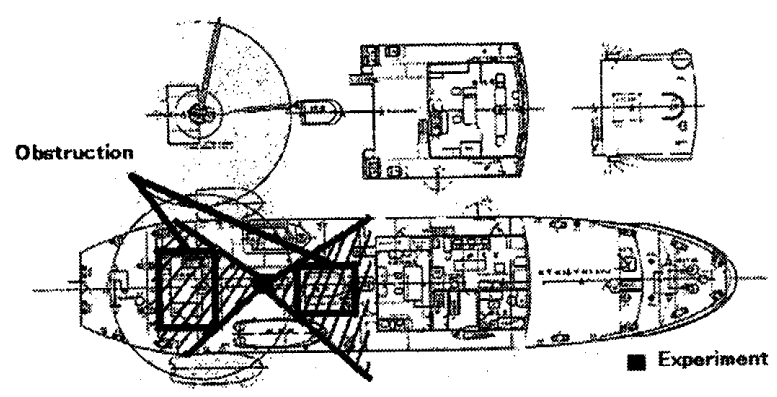

Fig.11 Installation Location

\section{2 实期落采}

館山沖で受信実験を行った結果を以下に示す。 
Fig.12・Fig.13・Fig.14 はそれぞれ実際の船の動摇（ロ ーリング・ピッチング・ヨーイング）と本システム の制御結果を示す水平プラットホーム上に置かれた 動摇計測計から得られた対応する運動である。それ ぞれの図において大きく摇れている波形は船の運動、 それに対して小さく変動している波形がプラットホ 一ムの対応する運動である。また Fig.15 は同時刻に 計测した BS 受信レベルである。Fig.15 に示すとお り、最初の 60 秒付近で電波が遮られアンテナ受信レ ベルが低下していることが確認される。

Fig.12・Fig.13・Fig.14より、通常航海時での動摇 程度では問題なく水平安定台部の安定度を 0.3 度以 内の水平度で保持していることが確認でき、当初の 目標である 0.5 度以内を上回った精度であることが わかる。また別途モ二ターした、BS・CS 放送の映 像も鮮明であった。

\section{5. 周波数领城での屏析}

Fig.15を見ると、前節で述べたとおり一部の時間 においてアンテナ受信レベルが低下している。また この区間以外でもわずかながらアンテナ受信レベル は上下しており、本装置が衛星を精度よく追尾しき れていない誤差も存在し、受信レベルに悪影響を及 ぼす可能性も捨て切れない。そのため、この原因を 探るべく、これらの実験結果をフーリ工解析しパワ 一スペクトラムを求め、本システムにおいてどれほ ど効果的に船体の動摇を打ち消し、衛星を追尾でき たのかを検証する。

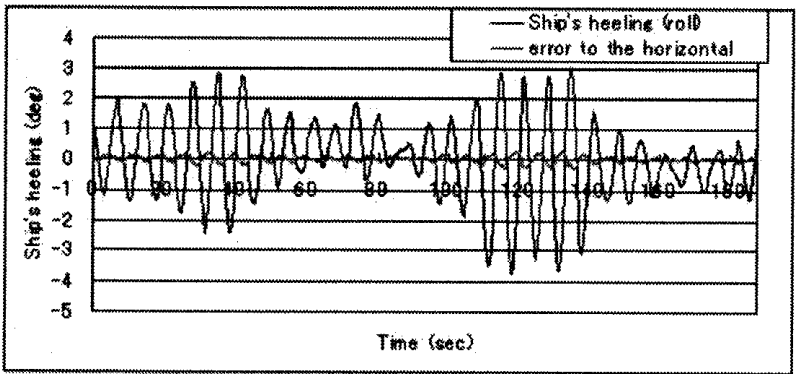

Fig.12 Rolling (on Deck and on Platform)

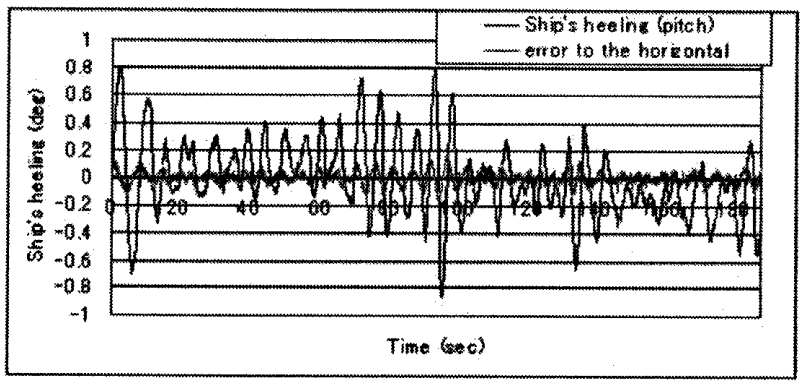

Fig.13 Pitching (on Deck and on Platform)

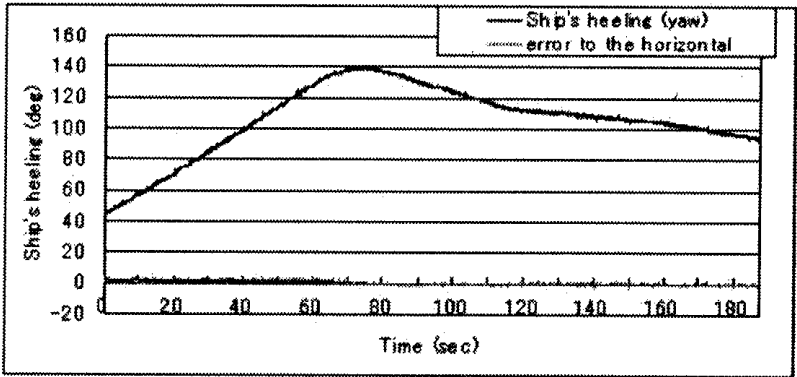

Fig.14 Yawing (on Deck and on platform)

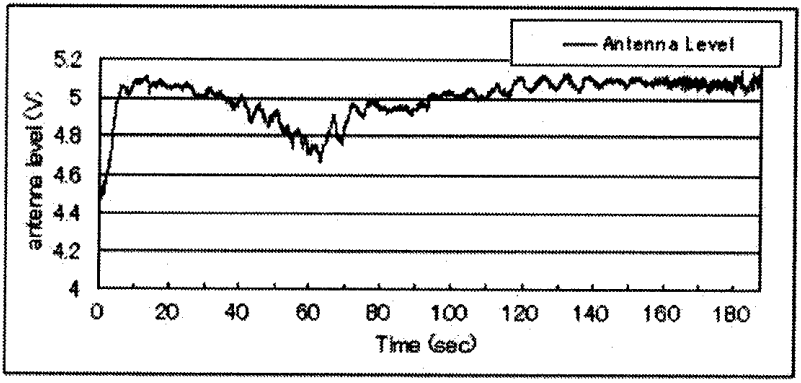

Fig.15 BS Antenna Level

\section{1 解析诘臬}

前節 4.2 の実験結果をスペクトラム解析したグラ フを示す。以下の単位はピークを強調するため動摇 角に対しては $\left[\mathrm{deg}^{2}\right] を \mathrm{~dB}$ に直して示している。ロ一 リングに対する解析結果は Fig.16に示す。図は実際 の船のローリングと水平台のローリングの水平度の スペクトラムを示す。Fig.17 はヨーイングと水平台 のヨーイングから求めたものである。いずれも大き い方の曲線は対応する船体動摇、小さい方の曲線は プラットホームの対応する動きである。ピッチング についてはロールリングと同様の傾向が見られたた め、紙面の都合から省略してある。

Fig.16のローリングに対するスペクトラムを見 ると、主要な周波数成分は実験に用いた練習船汐路 丸の固有周期であるおよそ $0.15 \mathrm{~Hz}$ 付近に集中して いることがわかる。これに対し水平安定台のローリ ングの数值を船体のローリング数值と比較すると、 本システムによって水平台は十分に減摇され、衛星 とのずれがなく追従しているといえる。

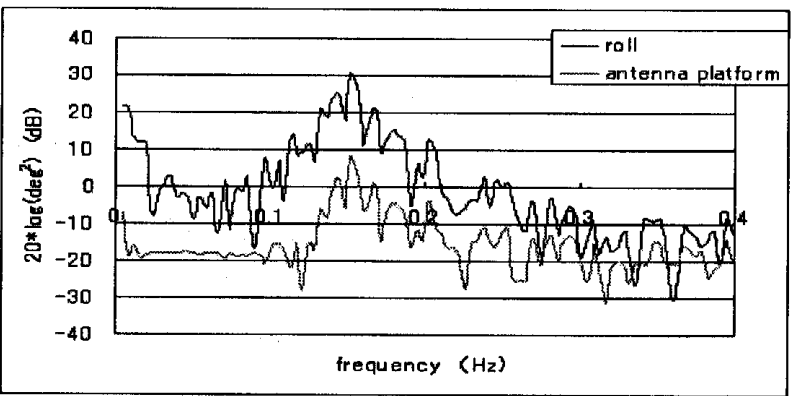

Fig.16 Rolling Spectrum (On ship and On Platform) 
Fig.17のヨーイングついても、ローリングと同様に 本システムによって大部分の周波数成分を取り除い ているといえるが、 $0.1 \mathrm{~Hz}$ までの長周期の成分を打 ち消し切れていない事が確認できる。そのためのア ンテナ受信レベルを示す Fig.18を見るとわかるよう に、アンテナ受信レベルはヨーイングと同様の周波 数成分を持っている。

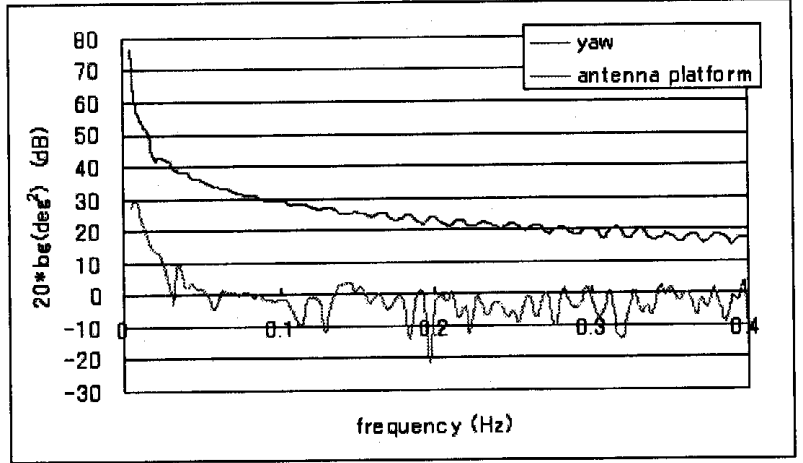

Fig.17 Yawing Spectrum (On ship and On platform)

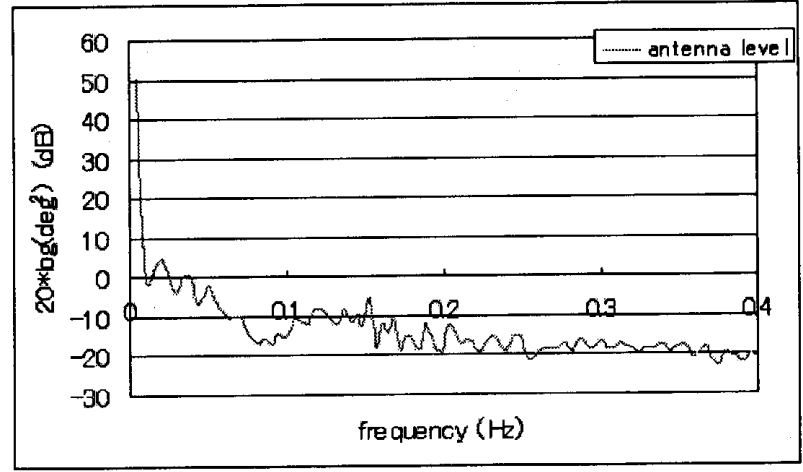

Fig.18 Antenna Level Spectrum

そこである運動要素への雑音が、アンテナレベル の変動にどの程度寄与するのかを示すノイズ寄与率 を求め、どの成分から強く影響を受けているのかを 詳細に調べた。ノイズ寄与率は,お互いに関連し合う 複数の変数から成るシステムにおいてある要素のス ペクトラムが自分自身も含めた他の変数からの影響 を受けるかを、周波数領域において全体を 1 とする 割合で表したものである ${ }^{(6)}$ 。

Fig.19 は、アンテナ受信レベルのスペクトラムへ 与える自身も含めた他の変数からの影響を周波数領 域で示した図である。図によるとアンテナ受信レベ ルの変動はローリング・ピッチングに入り込む雑音 によって形成されている部分は少なく、長周期領域 においてヨーイングからもっとも強く影響を受けて いる事がわかる。

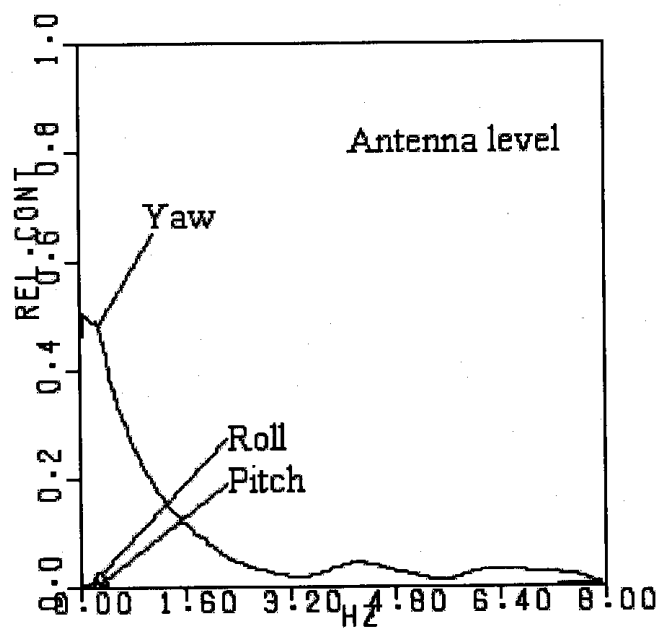

Fig.19 Noise Contributing Rate

\section{2 ヨーイング这徉精度の向上}

そこで、実船実験後、計測した旋回動摇デー夕を 元に、陸上においてシミュレーションを行ったとこ ろ、Fig.20に示すように目標值との誤差に定常偏差 が生じる事が確認できた。そしてこれらの実験から、 このヨーイングに定常誤差が発生する原因は、 $\mathrm{AR}$ モデルによる動きの予測間隔が不適切であったこと がわかった。これまではヨーイングのフィードフォ ワード制御にはアクチュエータの追従遅れを考慮し た上で、その予測の間隔をローリング・ピッチングと 同じにしていたが、Fig.21 に示すようにそれでは短 すぎることが原因であると考えられた。

このことから、Fig.22 に示すようにヨーイングに おける AR モデルによる予測のタイミングを長くし、 より先の船体の動摇を予測・出力することで、動摇 安定制御のさらなる精度向上を図った。この時の補 間には 3 次のラグランジュの補間多項式を用いて、 動摇安定台の動作が安定する間隔で制御を行った。

この予測区間の変更により、Fig.23に示すように、 ヨーイングの動摇に対する定常偏差は解消する事が 出来ることがわかった。

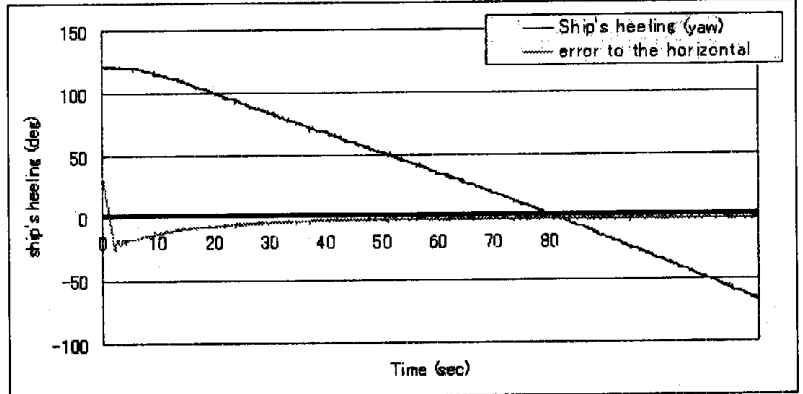

Fig.20 Revision of Prediction time (before) 


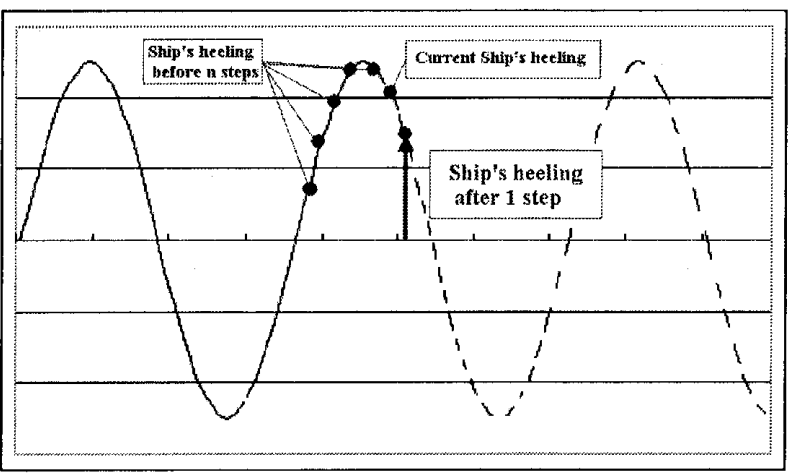

Fig.21 Prediction time (experiment at on-board)

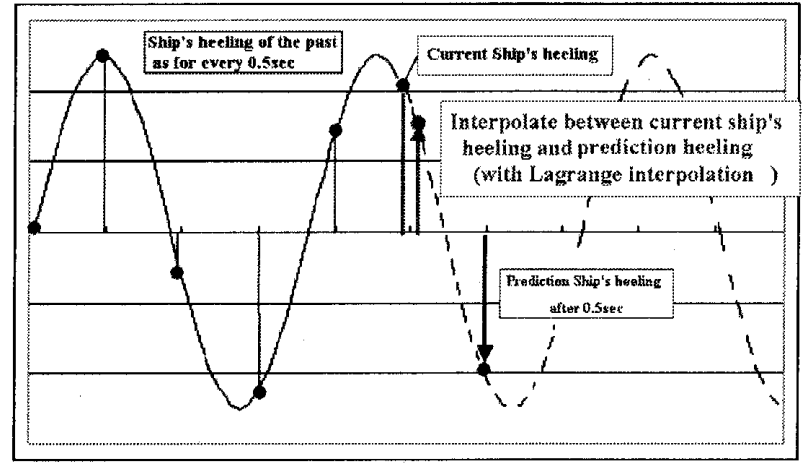

Fig.22 Prediction time (after revision)

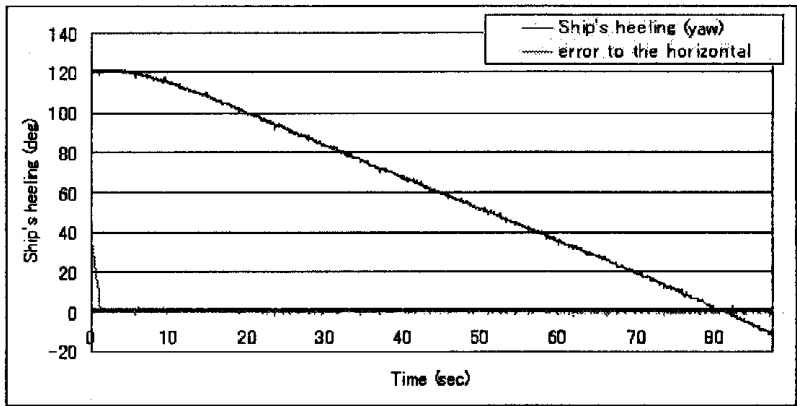

Fig.23 Revision of Prediction time (after)

\section{6. おわりに}

著者等は、東京海洋大学工学部で始めた船陸間通 信を現在よりできる限り高速・大容量化し、新たな 運航形態を創出しようとする海洋ブロードバンドプ ロジェクト（略称海洋 B B ）の要素の一つとして、 従来とは異なるまったく新しい夕イプのルネベルグ レンズアンテナを基本とする舶用衛星追尾アンテナ の開発をした。そして本研究ではそのうち特に受信 レベルの良否を左右するそのアンテナ部を支える水 平安定台（プラットフォーム）の追尾性能を検証し た。以下に検証試験により得られた項目を挙げる。

（1）システムに採用した動摇安定台により、要求 精度 0.5 度以下の誤差を上回る精度(最大誤差 0.3 度以下)で水平を保つことが出来た。

（2）ローリング、ピッチングに対する水平安定台

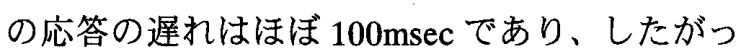
てこれらの運動の予測時間を 100msecにすれば
良いことがわかった。

（3）ヨーイングの船体動摇の制御は、実船実験で は若干満足し得るものではなかったが、通信を 行うには十分な精度であった。

（4）実船実験後、ヨーイングの制御を改善するた め陸上での動作シミュレーションを行い、ヨー イングの予測時間の見直しにより上項目の欠 点が改善される見込みがついた。

現時点では本システムは移動体アンテナとしての 許可が得られていないため、電波を送信する事が出 来ていない。そのため、速やかに許可を得るために も、更なる性能の向上を図り、送信実験を行ってい きたいと考える。

本研究の遂行に当たり、JSAT 社上瀬氏、住友電 工岸本氏およびコスメート社水野社長にお世話にな った。ここに深甚の感謝の意を表する。

\section{7. 考文献}

(1) D. Kraus et al 'Antennas for all Application' Mcgraw-Hill

（2）㸡野純・大津皓平・伊藤雅則:自己回帰モデルを 用いた動摇安定台に関する研究一 $\square$, 日本航海 学会論文集，第 103 号, pp.127-134(2000)

（3）鈴木雅人・南清和・大津皓平:動摇安定台の実用 化に関する研究一動摇シミュレーションによる 減摇効果の確認一, 日本航海学会論文集, 第 114 号, pp171-178(2006)

（4）飯田尚志:衛星通信，才ーム社

(5) Akaike, H. 'A New Look at the Statistical Model Identification' IEEE, Trans. on Automatic Control, vol. AC-19,No.6,pp.716-7231974

(6) 尾崎統(編), 北川源四郎(編), 赤池弘次:時系列解 析の方法, 朝倉書店

\section{8 震影店答}

萩原 季榯（東京海洋大学）：最初は 1 ステップ先 $(50 \mathrm{msec})$ 先の状態を予測して制御したということ ですが、何ステップ先を予測すれば最も有効な制 御が行えるのでしょうか。

朎木 雅人：今回の研究では制御サンプリングタイ ムに影響されずに、さまざまなタイミングでの予 測が行えるように改良をしました。そして、アク チュエータの追従遅れを実験結果より読み取り、 それを基準に実験を行いましたところ、およそ 2 ステップ先の $100 \mathrm{msec} の$ 予測を用いた結果がもっ とも有効であるとわかりました。 